\title{
Effects of Ocular Parameters on Medial Rectus Faden Operation with Recession for Esotropia*,**
}

\author{
Mustafa Doğan1, Birsen Gökyiğit², Serpil Akar³, Ömer Faruk Yılmaz ${ }^{4}$ \\ ${ }^{1}$ Department of Ophthalmology, School of Medicine, Afyonkarahisar Health Sciences University, Afyonkarahisar, Turkey \\ ${ }^{2}$ Department of Ophthalmology, Beyoğlu Eye Training and Research Hospital, İstanbul, Turkey \\ ${ }^{3}$ Department of Ophthalmology, School of Medicine, Başkent University, İstanbul, Turkey \\ ${ }^{4}$ Department of Ophthalmology, Private Office, İstanbul, Turkey \\ Email: mustafadogan@yahoo.com
}

How to cite this paper: Doğan, M., Gökyiğit, B., Akar, S. and Yilmaz, O.F. (2019) Effects of Ocular Parameters on Medial Rectus Faden Operation with Recession for Esotropia. Journal of Biosciences and Medicines, 7, 54-63.

https://doi.org/10.4236/jbm.2019.72005

Received: December 16, 2018

Accepted: January 30, 2019

Published: February 2, 2019

Copyright $\odot 2019$ by author(s) and Scientific Research Publishing Inc. This work is licensed under the Creative Commons Attribution International License (CC BY 4.0).

http://creativecommons.org/licenses/by/4.0/

\begin{abstract}
Background: In the treatment of infantile and accommodative esotopia medial rectus (MR) recession combined posterior fixation suture (Faden operation) can be used. But, there is very limited literature on effect of ocular parameters (axial length, medial rectus width and the distance of medial rectus insertion to limbus) to this operation. Objective: To evaluate effects of ocular parameters on medial rectus Faden operations with recession for esotropia. Material and Methods: In this retrospective study, 38 patients (57 eyes) who underwent Faden operation with unilateral or bilateral recession (4 - $4.5 \mathrm{~mm}$ ) on medial rectus were divided into three groups according to axial length, medial rectus width and the distance of medial rectus insertion to limbus. Preoperative and postoperative deviations compared. Results: 11 cases were infantile esotropia, 46 cases were acquired esotropia. Female/male rate was $19 / 19$. The mean preoperative amount of esotropia at near was 49.95 \pm 17.36 prism diopters (PD) and postoperative 1 week $11.77 \pm 11.14 \mathrm{PD}, 1$ month $12.02 \pm 11.52 \mathrm{PD}$ and 6 months $9.46 \pm 10.19 \mathrm{PD}$. The mean preoperative amount of esotropia at distance was $38.84 \pm 19.03 \mathrm{PD}$ and postoperative 1 week $7.25 \pm 11.29 \mathrm{PD}, 1$ month $6.54 \pm 10.52 \mathrm{PD}$ and 6 months $4.40 \pm 9.08 \mathrm{PD}$. Due to axial length, in shorter eyes, the decrease in mean postoperative deviation was statistically significant. Due to medial rectus width and the distance of medial rectus insertion, there was no statistically significant difference. Conclusions: Axial length has an effect on medial rectus Faden operations with recession but medial rectus width and
\end{abstract}

\footnotetext{
${ }^{\star}$ Presented partially as poster in The XIth meeting of the International Strabismological Association which was held at the Military Museum Conference Center on Sept. 22-25 in Istanbul, Turkey.

${ }^{* *}$ This manuscript derived from Mustafa Doğan's thesis on Faden operation for completing his residency in Beyoğlu Eye Training and Research Hospital.
} 
medial rectus insertion distance from limbus do not.

\section{Keywords}

Esotropia, Faden Operation, Axial Length, Medial Rectus Width, Medial

Rectus Distance from Limbus

\section{Introduction}

The management of essential infantile esotropia and convergence excess accommodative ET is highly controversial and has changed over the years. Some authors recommended bimedial rectus recession with the target angle. Others advocate adding posterior fixation suture to the medial rectus (MR) recession for controlling convergence excess ET. Other procedures such as marginal myotomy and slanted recession are less popular [1]-[6].

Many recommendations can be found in the literature about effectiveness of $\mathrm{MR}$ recession combined with posterior fixation suture (Faden operation) in high $\mathrm{AC} / \mathrm{A}$ ratio accommodative ET [3] [5] [6].

The term "faden" is the German word for suture or string [1]. The faden operation, also termed posterior fixation suture, first described by Cüppers in 1974 to treat incomitant strabismus [2].

It is used to weaken the rotational force of a rectus muscle when the eye rotates towards the faden muscle. The faden procedure is performed by suturing the rectus muscle to sclera, $12 \mathrm{~mm}$ to $14 \mathrm{~mm}$ posterior to the rectus muscle insertion. This pins the rectus muscle to the sclera so when the eye rotates towards the fadened muscle, the arc of contact cannot unravel. The faden suture thus creates a new insertion posterior to the original insertion. This posterior insertion shortens the moment arm when the eye rotates towards the fadened muscle. Shortening the moment arm reduces the rotational force as the eye rotates towards the fadened muscle [1].

The faden operation may be helpful when the patient has an esotropia with a high AC/A ratio. Other indications for the faden operation have been reported including sixth nerve paresis, dissociated vertical deviation, nystagmus compensation syndrome, and nystagmus in primary position without a face turn. In addition, some have advocated using the faden operation on the lateral rectus muscle in patients with Duane's retraction syndrome, and significant upshoot and downshoot [1] [3] [4] [5].

In the literature, there is very limited knowledge on effect of ocular parameters on this operation. Do axial length, medial rectus width and the distance of medial rectus insertion to limbus have effect on success rate?

The aim of this study is to evaluate effects of ocular parameters (axial length, medial rectus width and the distance of medial rectus insertion to limbus) on medial rectus Faden operations with recession for esotropia. 


\section{Patients and Methods}

\subsection{Study Design}

In this retrospective study, the medical records from 38 patients who underwent the Faden operation on medial rectus muscles with recession for the treatment of esotropia between December 2005 to February 2007 in Beyoglu Eye Research and Training Hospital in İstanbul were reviewed.

The study was approved by the ethics committee of the Istanbul Professor Dr. $\mathrm{N}$ Reşat Belger Beyoglu Education and Research Eye Hospital Institutional Review Board. The study and the data collection conformed to all local laws and were compliant with the principles of the Declaration of Helsinki.Informed consent was obtained from each participant; for children younger than 18 years of age, consent was obtained from one or both of the parents.

\subsection{Examination}

Inclusion criteria were accommodative and partially accommodative esotropia (refractive or nonrefractive) and esotropia at near exceeding esotropia at distance by at least 10 prism diopters (PD).

Exclusion criteria were ocular or systemic diseases, a history of previous intraocular or strabismus surgery, neurological or developmental disorders, and a follow-up period of less than 1 year. Patients who had undergone concurrent oblique muscle surgery were also excluded.

The patients underwent a standard ophthalmologic examination, including refraction (cycloplegic refraction via sciascopy and autorefractokeratometer, best corrected visual acuity, slit-lamp biomicroscopy, and detailed funduscopy. Visual acuity measurements were obtained with Snellen charts or Lea symbols. Ocular motility was evaluated with alternate prism and cover testing at $6 \mathrm{~m}$ and $33 \mathrm{~cm}$ and with the Krimsky test for patients of a younger age. Ductions and versions were examined and documented using traditional methods. Examinations were performed preoperatively and postoperatively at 1,3, and 6 months.

\subsection{Surgical Procedure}

All surgeries were performed by one surgeon (B.G.) under general anaesthesia. All patients received a posterior fixation suture on one or both medial rectus muscles at 12.50 or $13.50 \mathrm{~mm}$ from the insertion of the muscle with a nonabsorbable suture (5.0 Ethibond Excel (Ethicon, Somerville, NJ)). After careful dissection of the connective tissues around the muscle, the suture was fixed to the sclera on both sides of the muscle and a knot was made (Figure 1). In the recession group, unilateral or bilateral recession $(4-4.5 \mathrm{~mm})$ was done and the Faden operation was performed followed by medial rectus recession.

A posterior fixation suture was performed based on the modified method of Cuppers described by de Decker [4], and recommended guidelines based on the degree of esotropia were followed [4]. MR muscles were sutured at $12.50-13.50 \mathrm{~mm}$ 


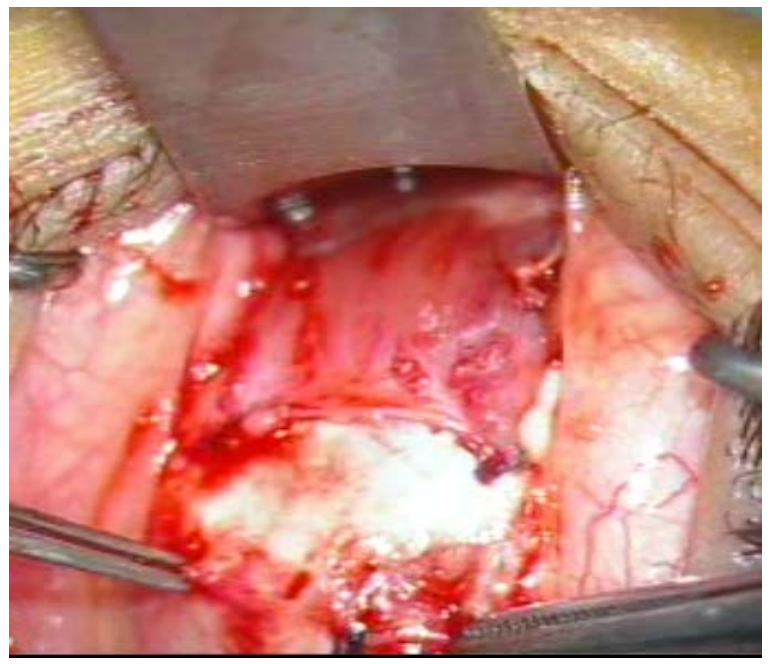

Figure 1. Faden suturing.

from the insertion based on the angle of deviation $(12.50 \mathrm{~mm}$ from the insertion for 20 - $30 \mathrm{pd}$ of deviation angle, $13 \mathrm{~mm}$ for $40 \mathrm{pd}, 13.50 \mathrm{~mm}$ for $\geq 50 \mathrm{pd}$ ).

Postoperatively, orthotropia or esotropia of $<10 \mathrm{pd}$ at near and distance fixations with available optical correction and an elimination of near-distance disparity were jointly considered to be a satisfactory outcome.

Preoperative and postoperative axial length, medial rectus width and the distance of medial rectus insertion to limbus were obtained. According to axial length, medial rectus width and the distance of medial rectus insertion to limbus cases were divided into three groups (axial length; $\leq 21 \mathrm{~mm}, 21-22 \mathrm{~mm}, \geq 22$ $\mathrm{mm}$. medial rectus width; $\leq 10.50 \mathrm{~mm}, 10.50-12 \mathrm{~mm}, \geq 12 \mathrm{~mm}$. The distance of medial rectus insertion to limbus; $\leq 4.25 \mathrm{~mm}, 4.25-5 \mathrm{~mm}, \geq 5 \mathrm{~mm}$ ). All groups were compared according to preoperative and postoperative deviation.

\subsection{Data Analysis}

The Statistical Package for the Social Sciences (SPSS) software (version 11; SPSS, Inc., Chicago, IL) was used for the data analysis. Categorical variables were presented as numbers, and numerical variables were expressed as means and standard deviations. The Kolmogorov-Smirnov test was used to assess the normal distribution of the data and the Mann-Whitney, Kruskal-Wallis and Paired Sample Test used. A $P$ value of less than 0.05 was considered statistically significant.

\section{Results}

11 eyes were infantile esotropia, 46 eyes were acquired esotropia. Female/male rate was 19/19.

The comparison of deviations at distance and at near between preoperative and postoperative 1 week, 1 month and 6 months were statistically significant, (Tables 1-7, Figure 2 and Figure 3). After surgery, the amount of deviation decreased both at distance and near fixation. 


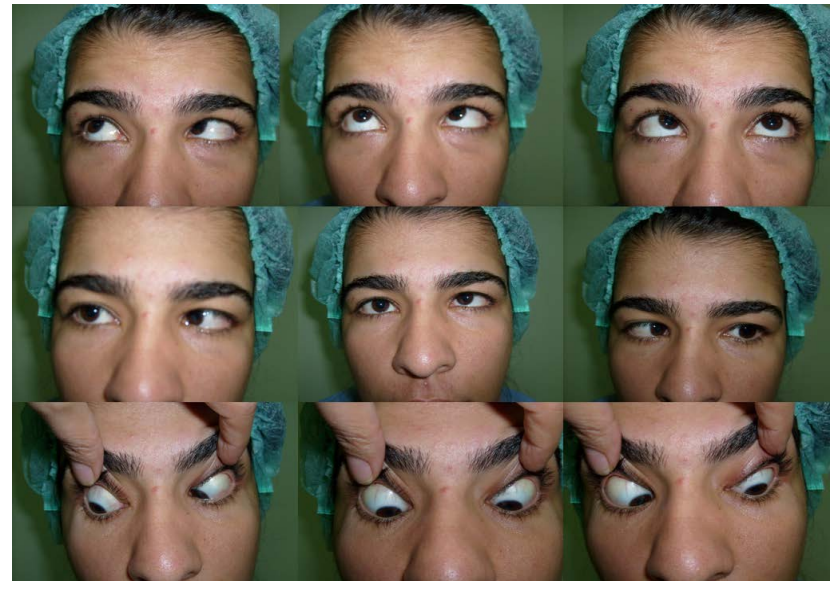

Figure 2. 70 PD ET preoperative.

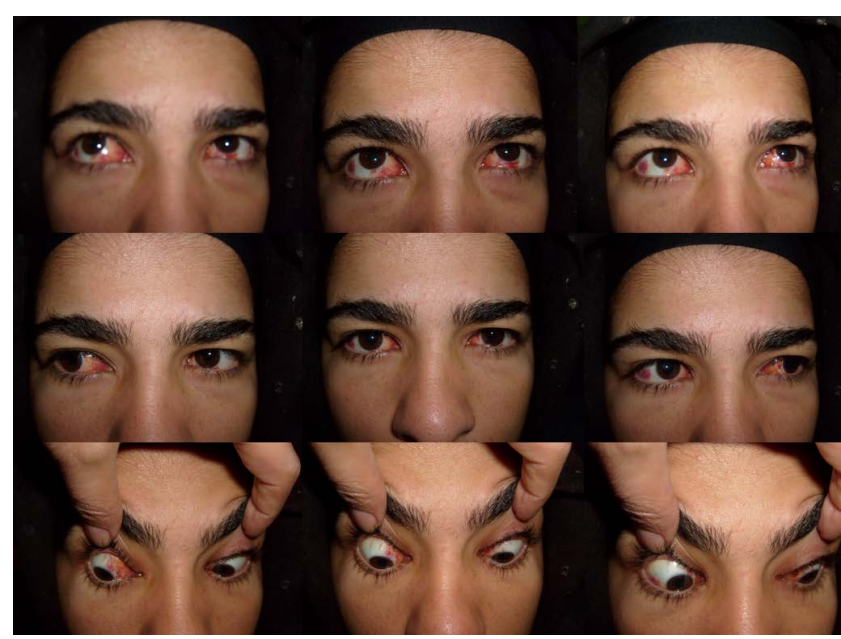

Figure 3. After 1 week Bimedial $4 \mathrm{~mm}$ recession $+13.50 \mathrm{~mm}$ Faden operation.

Table 1. Surgical data.

\begin{tabular}{|c|c|c|}
\hline Type of Operation & Amount of case and (\%) & Amount of recession and Faden \\
\hline Unilateral recession $+\mathrm{Fd}$ & $19(50 \%)$ & $\begin{array}{c}4.342 \pm 0.239 \mathrm{~mm} \text { recession } \\
\text { and } 13.01 \pm 0.32 \mathrm{~mm} \mathrm{Fd}\end{array}$ \\
\hline Bilateral recession $+\mathrm{Fd}$ & $19(50 \%)$ & $\begin{array}{c}4.302 \pm 0.248 \mathrm{~mm} \text { recession } \\
\text { and } 12.84 \pm 0.22 \mathrm{~mm} \text { Fd }\end{array}$ \\
\hline Total & $38(100 \%)$ & $\begin{array}{c}4.324 \pm 0.241 \mathrm{~mm} \text { recession } \\
\text { and } 12.89 \pm 0.27 \mathrm{~mm} \mathrm{Fd}\end{array}$ \\
\hline
\end{tabular}

Table 2. Preoperative and postoperative 1 week deviations, correction amounts, correction percentage and $\mathrm{p}$ value at distance.

\begin{tabular}{cccccc}
\hline & $\begin{array}{c}\text { Preop } \\
\text { Deviation PD }\end{array}$ & $\begin{array}{c}\text { Postop } \\
1 \text { week PD }\end{array}$ & $\begin{array}{c}\text { Correction } \\
\text { PD }\end{array}$ & Correction \% & P value \\
\hline Unilateral MD \pm SD & $27.68 \pm 15.13$ & $5.63 \pm 6.70$ & 22.05 & 92.1 & $<0.001$ \\
Bilateral MD \pm SD & $44.42 \pm 18.46$ & $8.05 \pm 11.88$ & 36.37 & 81.84 & $<0.001$ \\
Total MD \pm SD & $38.84 \pm 19.03$ & $7.25 \pm 1.29$ & 77.96 & 77.96 & $<0.001$ \\
\hline
\end{tabular}


Table 3. Preoperative and postoperative 1 week deviations, correction amounts, correction percentage and $\mathrm{p}$ value at near.

\begin{tabular}{cccccc}
\hline & $\begin{array}{c}\text { Preop } \\
\text { Deviation PD }\end{array}$ & $\begin{array}{c}\text { Postop } \\
1 \text { week PD }\end{array}$ & $\begin{array}{c}\text { Correction } \\
\text { PD }\end{array}$ & $\begin{array}{c}\text { Correction } \\
\%\end{array}$ & P value \\
\hline Unilateral MD \pm SD & $37.74 \pm 4.52$ & $10.74 \pm 9.72$ & 27.00 & 66.82 & $<0.001$ \\
Bilateral MD \pm SD & $56.05 \pm 5.43$ & $12.29 \pm 11.88$ & 43.76 & 79.28 & $<0.001$ \\
Total MD \pm SD & $49.95 \pm 17.35$ & $11.77 \pm 11.14$ & 38.18 & 75.12 & $<0.001$ \\
\hline
\end{tabular}

Table 4. Preoperative and postoperative 1 month deviations, correction amounts, correction percentage and $\mathrm{p}$ value at distance.

\begin{tabular}{cccccc}
\hline & $\begin{array}{c}\text { Preop } \\
\text { Deviation PD }\end{array}$ & $\begin{array}{c}\text { Postop } \\
1 \text { month PD }\end{array}$ & $\begin{array}{c}\text { Correction } \\
\text { PD }\end{array}$ & $\begin{array}{c}\text { Correction } \\
\%\end{array}$ & P value \\
\hline Unilateral MD \pm SD & $27.68 \pm 15.13$ & $5.74 \pm 11.30$ & 21.95 & 92.1 & $<0.001$ \\
Bilateral MD \pm SD & $44.42 \pm 18.46$ & $6.95 \pm 10.24$ & 37.47 & 85.95 & $<0.001$ \\
Total MD \pm SD & $38.84 \pm 19.03$ & $6.54 \pm 10.52$ & 32.3 & 87.99 & $<0.001$ \\
\hline
\end{tabular}

Table 5. Preoperative and postoperative 1 month deviations, correction amounts, correction percentage and $p$ value at near.

\begin{tabular}{cccccc}
\hline & $\begin{array}{c}\text { Preop } \\
\text { Deviation PD }\end{array}$ & $\begin{array}{c}\text { Postop } \\
1 \text { month PD }\end{array}$ & $\begin{array}{c}\text { Correction } \\
\text { PD }\end{array}$ & $\begin{array}{c}\text { Correction } \\
\%\end{array}$ & P value \\
\hline Unilateral MD \pm SD & $37.74 \pm 4.52$ & $12.16 \pm 12.71$ & 25.58 & 67.11 & $<0.001$ \\
Bilateral MD \pm SD & $56.05 \pm 5.43$ & $11.95 \pm 11.06$ & 44.11 & 79.31 & $<0.001$ \\
Total MD \pm SD & $49.95 \pm 17.35$ & $12.02 \pm 11.52$ & 37.93 & 75.24 & $<0.001$ \\
\hline
\end{tabular}

Table 6. Preoperative and postoperative 6 month deviations, correction amounts, correction percentage and $\mathrm{p}$ value at distance.

\begin{tabular}{cccccc}
\hline & $\begin{array}{c}\text { Preop } \\
\text { Deviation PD }\end{array}$ & $\begin{array}{c}\text { Postop } \\
6 \text { month PD }\end{array}$ & $\begin{array}{c}\text { Correction } \\
\text { PD }\end{array}$ & $\begin{array}{c}\text { Correction } \\
\%\end{array}$ & P value \\
\hline Unilateral MD \pm SD & $27.68 \pm 15.13$ & $4.37 \pm 11.05$ & 23.32 & 94.65 & $<0.001$ \\
Bilateral MD \pm SD & $44.42 \pm 18.46$ & $4.42 \pm 8.08$ & 40 & 90.59 & $<0.001$ \\
Total MD \pm SD & $38.84 \pm 19.03$ & $4.40 \pm 9.08$ & 34.44 & 91.94 & $<0.001$ \\
\hline
\end{tabular}

Table 7. Preoperative and postoperative 6 month deviations, correction amounts, correction percentage and $\mathrm{p}$ value at near.

\begin{tabular}{cccccc}
\hline & $\begin{array}{c}\text { Preop } \\
\text { Deviation PD }\end{array}$ & $\begin{array}{c}\text { Postop } \\
6 \text { month PD }\end{array}$ & $\begin{array}{c}\text { Correction } \\
\text { PD }\end{array}$ & $\begin{array}{c}\text { Correction } \\
\%\end{array}$ & P value \\
\hline Unilateral MD \pm SD & $37.74 \pm 4.52$ & $10.26 \pm 11.22$ & 27.47 & 71.8 & $<0.001$ \\
Bilateral MD \pm SD & $56.05 \pm 5.43$ & $9.05 \pm 9.77$ & 47 & 84.72 & $<0.001$ \\
Total MD \pm SD & $49.95 \pm 17.36$ & $9.46 \pm 10.19$ & 40.49 & 80.41 & $<0.001$ \\
\hline
\end{tabular}


According to medial rectus width and the distance of medial rectus insertion to limbus, between in all three groups comparison of correction in deviation, the difference was not statistically significant. But according to axial length between in all three groups comparison of correction in deviation, the difference was statistically significant. In $\leq 21 \mathrm{~mm}$ group the correction was higher than $21-22$ $\mathrm{mm}$ group and $\geq 22 \mathrm{~mm}$ group. And in $21-22 \mathrm{~mm}$ group correction was higher than $\geq 22 \mathrm{~mm}$ group. So when axial length is shorter the correction in deviation was higher (Table 8 and Table 9).

\section{Discussion}

In esotropia treatment with posterior fixation suture with or without MR muscle recession is controversial [3] [4] [6] [7] [8]. And also, The Faden procedure is a difficult surgery and has some complications like glob perforation. Becuase muscles are sutured posteriorly, behind the equator and near to the vortex veins. Experienced surgeons can minimise the risk of complications.

Although it has some disadvantages, we found that Faden operation with or without MR muscle recession is effective for the treatment of esotropia.

Some authors reported that $76 \%-86 \%$ of patients with convergence excess were capable.

of maintaining satisfactory near ocular alignment with bilateral Faden operations on the MR muscles at an average of 2 - 3 years of follow-up [7]. In our studies, $80.4 \%$ of cases showed satisfactory near ocular alignment.

Table 8. Findings in axial length group.

\begin{tabular}{ccccc}
\hline Axial Length & $\begin{array}{c}\text { Preoperative } \\
\text { Deviation } \\
\text { At Distance PD }\end{array}$ & $\begin{array}{c}\text { Preoperative } \\
\text { Deviation } \\
\text { At Near PD }\end{array}$ & $\begin{array}{c}\text { Postoperative } \\
6 \text { month } \\
\text { Deviation } \\
\text { At Distance PD }\end{array}$ & $\begin{array}{c}\text { Postoperative } \\
6 \text { month } \\
\text { Deviation } \\
\text { At Near PD }\end{array}$ \\
\hline $21 \mathrm{~mm}$ & $36.42 \pm 13.41$ & $46.42 \pm 12.13$ & $-1.25 \pm 4.33$ & $1.00 \pm 5.88$ \\
$\mathrm{MD} \pm \mathrm{SD}$ & $36.92 \pm 16.50$ & $48.81 \pm 15.70$ & $5.96 \pm 10.37$ & $11.38 \pm 10.86$ \\
$21.00-22.00 \mathrm{~mm}$ & & & $5.84 \pm 8.27$ & $12.16 \pm 8.81$ \\
$\mathrm{MD} \pm \mathrm{SD}$ & $43.00 \pm 24.72$ & $53.74 \pm 21.89$ & & \\
\hline $22 \mathrm{~mm}$ & & & &
\end{tabular}

Table 9. Findings in axial length group.

\begin{tabular}{ccc}
\hline Axial Length & $\begin{array}{c}\text { Mean Correction } \\
\text { At Distance PD \& } \%\end{array}$ & $\begin{array}{c}\text { Mean Correction } \\
\text { At Near PD \& \% }\end{array}$ \\
$\leq 21 \mathrm{~mm}$ group & $37.67 \pm 15.05$ & $45.42 \pm 13.43$ \\
$\mathrm{MD} \pm \mathrm{SD}$ & $102.08 \% \pm 12.87 \%$ & $97.12 \% \pm 13.45 \%$ \\
$21.00-22.00 \mathrm{~mm}$ group & $30.96 \pm 15.25$ & $37.42 \pm 16.67$ \\
$\mathrm{MD} \pm \mathrm{SD}$ & $91.37 \% \pm 45.60 \%$ & $76.36 \% \pm 22.70 \%$ \\
$\geq 22 \mathrm{~mm}$ group & $37.16 \pm 23.82$ & $41.58 \pm 19.72$ \\
$\mathrm{MD} \pm \mathrm{SD}$ & $86.30 \% \pm 26.27 \%$ & $75.42 \% \pm 18.99 \%$ \\
\hline
\end{tabular}


De Decker, evaluated 235 patients who had a Faden procedure on the MR muscles and reported that $181(76.5 \%)$ acheived a satisfactory outcome after 2 3 years of follow-up [4]. In our series, a satisfactory outcome of $91.94 \%$ at 6 month postoperatively. But, our follow-up time is not as long as de Decker. And some authors reported that by the time the effectiveness of this surgery decreases [3]. So, maybe by the time our patients' satisfactory outcomes would decrease.

Akar et all reported that $7.9 \%$ showed secondary exotropia at an average of 4.8 years of follow-up [3]. In our study, 6 Month postoperatively, only 3 patient had overcorrection.

Von Noorden performed Faden operations on previously recessed MR muscles in 12 patients with a persistent convergence excess-type esotropia. He reported that the operation reduced the deviation in all but one patient and was more effective at near fixation than at distance fixation [9]. In our series, reduction of the near deviation was higher than reduction of the distance deviation after 6 month postoperatively.

Medial rectus muscle width is $10.30 \mathrm{~mm}$ on average [10]. In our study mean medial rectus muscle width was $11.09 \pm 1.06 \mathrm{~mm}$. To the best of our knowledge there is no data on relationship between postoperative correction of deviation and MR muscle width in conventional strabismus surgery and Faden surgery. In our study we did not find any correlation. There was no effect of MR muscle width on Faden operation. This may be due to $1 / 3$ of muscle fixation on sclera.

Mims et al. did not find any correlation on deviation amounts and the distance of medial rectus muscle insertion to limbus in infantile esotropia patients [11]. In our study, mean distance of medial rectus muscle insertion to limbus was $4.78 \pm 0.59 \mathrm{~mm}$. There was no correlation between postoperative correction amount of deviation and distance between muscle insertion to limbus.

Kushner et al. found that there was an inverse correlation between axial length and correction in deviation in conventional esotropia surgery [12]. In our study, our findings were similar. In patients with longer axial lengths, the amount of deviation corrections was smaller. In patients with shorter axial lengths, the corrections were bigger.

Krzizok et al. found that there was an inverse correlation between axial length and correction in deviation in faden operation in esotropia surgery [13]. In eyes with longer axial length, correction in deviation decreased.

A limitation of this study is that it does not include controls. But, it is understandable that to establish a control group is very difficult and time assuming and also there are some ethical issues.

\section{Conclusions}

Faden operations, unilaterally or bilaterally, on MR muscles with recession were a successful surgical treatment option that resulted in the reduction of the near and distance deviations in esotropia. 
In eyes with shorter axial lengths, the decrease of postoperative deviations was more than longer axial lengths. The medial rectus width and the distance of medial rectus insertion to limbus had no effect on Faden surgery.

\section{Availability of Data and Materials}

The datasets used and/or analyzed during the current study are available from the corresponding author on reasonable request.

\section{Conflicts of Interest}

The authors declare that they have no competing interests.

\section{References}

[1] Wright, K.W. (2007) Color Atlas of Strabismus Surgery Strategies and Techniques. Springer, New York, Vol. 20, 200-201.

[2] Cüppers, C. (1976) The So-Called "Fadenoperation.” ISecond Congress of the International Strabismological Association. Marseilles; Diffusion Générale de Librairie, 395-400.

[3] Akar, S., Gokyigit, B., Sayin, N., Demirok, A. and Yilmaz, O.F. (2013) Medial Rectus Faden Operations with or without Recession for Partially Accommodative Esotropia Associated with a High Accommodative Convergence to Accommodation Ratio. British Journal of Ophthalmology, 97, 83-87.

https://doi.org/10.1136/bjophthalmol-2012-302175

[4] de Decker, W. (1981) The Faden Operation. When and How to Do It. Transactions of the Ophthalmological Societies of UK, 101, 264-270.

[5] Clark, R.A., Isenberg, S.J., Rosenbaum, A.L., et al. (1999) Posterior Fixation Sutures: A Revised Mechanical Explanation for the Fadenoperation Based on Rectus Extraocular Muscle Pulleys. American Journal of Ophthalmology, 128, 702-714. https://doi.org/10.1016/S0002-9394(99)00356-6

[6] Khalifa, Y.M. (2011) Augmented Medial Rectus Recession, Medial Rectus Recession Plus Faden, and Slanted Medial Rectus Recession for Convergence Excess Esotropia. European Journal of Ophthalmology, 21, 119-124. https://doi.org/10.5301/EJO.2010.5225

[7] Thouvenin, D.A., Sotiropoulos, M.C., Arne, J.L., et al. (2008) Esotropias That Totally Resolve under General Anesthesia Treated Exclusively with Bilateral Fadenoperation. Strabismus, 16, 131-138. https://doi.org/10.1080/09273970802505284

[8] Gharabaghi, D. and Zanjani, L.K. (2006) Comparison of Results of Medial Rectus Muscle Recession Using Augmentation, Faden Procedure, and Slanted Recession in the Treatment of High Accommodative Convergence/Accommodation Ratio Esotropia. Journal of Pediatric Ophthalmology and Strabismus, 43, 91-94.

[9] von Noorden, G.K. (1982) An Alternative to Marginal Myotomy. American Journal of Ophthalmology, 94, 285-289. https://doi.org/10.1016/0002-9394(82)90352-X

[10] Christian, C.J., Biglan, A.W. and Josef, H.C. (2002) Surgery for Esotropia. Duane's Clinical Ophthalmology on CD-Rom, 6: Ch. 84.

[11] Mims $3^{\text {rd }}$, J.L. (1981) Medial Rectus Insertion Site in Congenital Esotropia. Canadian Journal of Ophthalmology, 16, 181-186. 
[12] Kushner, B.J., Lucchese, N.J. and Morton, G.V. (1989) The Influence of Axial Length on the Response to Strabismus Surgery. Arch Ophthalmol, 107, 1616-1618. https://doi.org/10.1001/archopht.1989.01070020694030

[13] Krzizok, T., Gräf, M. and Kaufmann, H. (1994) Effect of Bulbus Length of Reduction of Squint Angle after Suture Fixation. Ophthalmologe, 91, 68-76. 